\title{
ANALYSIS OF THE RESULTS OF THE PEDAGOGICAL RESEARCH AND EEG IN THE ASPECT OF EFFECTIVE MODERN TEACHING AIDS IN THE TECHNICAL EDUCATION
}

\author{
Tomasz Prauzner \\ Institute of Technological and Safety Education, \\ Jan Długosz University, Częstochowa, Poland
}

\begin{abstract}
The development of computer technology is reflected in among other things, the development of modern didactics. Current pedagogy and media education, as a fast developing discipline of general pedagogy, is a topic of a number of studies. Applying the modern multimedia aids at various stages and in various types of education is considered as an indispensable element of modern didactics, due to new opportunities the modern media offers. The paper deals with didactic innovations based on research conducted within pedagogy on the observable social changes induced by development in information technology. The main objective of the paper is to address the issue how to apply modern technology and research findings on the functioning of the brain in order to improve the effectiveness of the learning process. The paper presents only the results of a pilot study, which can be used as a basis for further research using medical equipment for analyzing EEG brain waves for didactic purposes.
\end{abstract}

Keywords: IT, computer simulation, neurodidactics, multimedia, media education, didactics, information society.

\section{Introduction}

The ability to operate personal computers and related IT devices is an indispensible skill in modern information society. For the young generation to develop the skill, they are to be regularly and permanently exposed to the latest achievements in technology. That is why it is vital to popularize the idea of information technology in the school in various forms and at various levels of education, from kindergarten to university. The development of computer technology is reflected, among others, in the development of modern didactics. It has to be noted that the education programmes and curricula, although developed by outstanding specialists, may become outdated before they actually reach the classroom. The publishing of textbooks may take even years so that teachers are often rightly concerned about the validity and currency of the textbook content. Sometimes, in the pursuit of their individual interests, students get updated about the latest scientific and technological findings by surfing the Internet. (Freedman, 2011; Gerhard, 2011) On the one hand, it is a positive phenomenon, on the other hand it makes educators think how to keep teaching curricula updated. This, in turn, implies further questions: how to pass on the 
knowledge by means of modern and more attractive teaching aids? The main purpose of the didactic process is to transfer as much knowledge as possible, in the most effective and fastest way, activating the learner to perform tasks individually and thereby raising his/her interest in the subject, helping to acquire the knowledge permanently. Like other subjects of academic research, didactics also follows the changes in the social environment and its range of interest concerns meeting current requirements in the field of education. (Carr, 2012)

A young person should be able to face a new role and challenges of living in an information society, the role based on the recent developments in electronics and information technology. Education is this area has to be a multistage process starting as early as possible and offering a chance of learning how to use modern technology in the process of education and later in work. A widely known model of the didactic activity relations between teachers and students T-S (Fig.1) does not sufficiently reflect the reactions between the subjects.

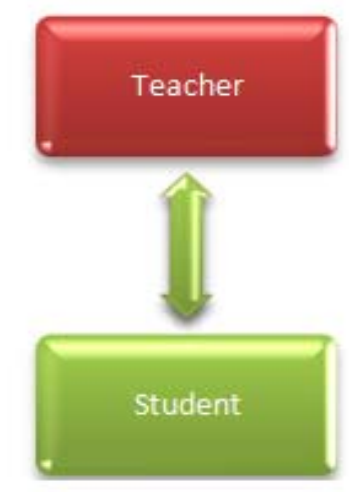

Figure 1. The model of the didactic activity relations between teachers and students (T-S)

A current model of presented relations should be undoubtedly enriched by the additional subjects that take part in the given process. One of the elements is the didactic material (DM) and didactic computer programme (DCP). The above presented plane model which consists of two basic subjects: a teacher (T) and students $(\mathrm{S})$ transforms into the spatial system represented by the Fig. 2. The given model can be called the new model or otherwise heuristic-ergonomic model.

At the deeper graphic analysis, this model also interprets power of the connection of each elements (apexes). Their value represents a length of a vector or their mutual system (the resultant). The didactic tetrahedron shows the didactic space with an undefined number of possible didactic situations. Each of the situations can be materialized inside by four vectors led out of every apex of the tetrahedron - the pole. The location of particular didactic situation intensifies the interconnections, which allows to the univocal presentation of the correlation of each subjects. (Barski, 1998; Prauzner, 2010) 


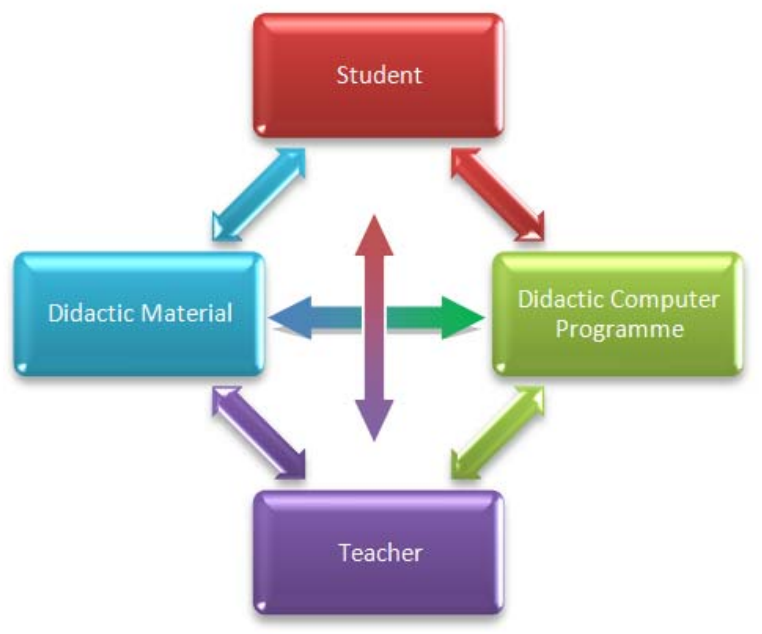

Figure 2. The model of the didactic activity relations T-S-DM-DCP - the didactic tetrahedron

Institute of Technological and Safety Education offers full-time and parttime studies for future engineers of the following specializations: Management of Health and Safety and Occupational and Environmental Safety. Three-term post-graduate courses Education for Safety are intended especially for teachers who gain knowledge necessary for teaching such subjects as Education for Safety, Pro-health Education, or Civil Protection. At present the OHS education is conducted in line with current trends in teaching methodology and forms of communication. Classes take place in laboratories and classrooms equipped with multimedia facilities. Field activities organized in companies and civil service institutions are also considered to be attractive. The instructors are highly qualified specialists dealing with various domains of safety. They conduct lectures, classes, field activities and laboratory classes using advanced didactic aids. Due to technological new solutions simulation programs more and more in reality are copying reality of phenomena. During teaching for electrical engineering laboratory practical exercises are conducted with the measurement of the parameter inductive sensors. The operation of these sensors can also be simulated in specialized programs and the results compared with actual measurements. Inductive sensors are widely used as magnetic field sensors for threat detection and alarm systems (Ptak \& Borowik, 2012; Ptak \& Prauzner, 2013). The operation of these sensors can also be simulated in specialized programs and the results compared with actual measurements.(Janiczek \& Ptak, 2007; Prauzner \& Ptak, 2014)

This method consists in giving appropriate incentives stimulating, being aimed possibly to all senses into the way as most faithful copying the reality of the happening occurrence. The components of a computer simulation, then, are as follows: the system in which relations between objects hold and the physical 
and mathematical models being the basis of computer simulation by the user. A computer simulation offers a highly reliable representation of conditions obtaining in the real world as well as actions exerted upon the object examined. Because of that, computer simulations are a viable alternative to analytical methods, which may not always be applicable to solving problems of high complexity.

\section{Methods of Research}

Scientific studies have been carried out on the basis of two methods. The first -in 2012/13 academic year the research conducted on the classical methodology involving statistical analysis of teaching effects, e.g. grades obtained by students of Technological and Safety Education - Jan Długosz Academy in Częstochowa, Poland. I conducted the stage with 118 students participating in the survey. In order to conduct the research, I separated from the existing laboratory groups - the experimental groups, from both computer and electro - electronic classes. In those groups I held classes personally, which made it possible to introduce innovation into the course of classes and a thorough evaluation of the learning progress. During this stage of research, I introduced to the experimental group new didactic solutions, which were based on new didactic measures with the use of multimedia techniques, especially simulation programs based on: FEM (Finite Element Method), FDS (Fire Dynamics Simulator), A* Search Algorithm and another technology. The control group also participated in the research, without having any innovations introduced. Computer simulations make it possible to visualize the teaching process, facilitate reasoning and help students in performing tasks and developing practical skills. The independent variables assumed in the study were: the initial state of knowledge in the students before the experiment started, the number of students under scrutiny and the didactic aids used in both groups (transparencies, multimedia presentations, academic course books and computer programmes). In the experimental group the classes were conducted in a computer room, using individual computer stands with simulation software. They started with a short presentation stating the aim of the class and explaining how to use the simulation programme. The classes in the control group were conducted in the traditional form, by giving instructions, presentations and using a course book. Since the effectiveness of the didactic process is a complex issue which can be interpreted by means of a number of factors, the study analyses selected dependent variables on the basis of which it is possible to determine this kind of effectiveness. These variables include:

a) Learning new information, or acquisition of new knowledge. The indicator of which was assumed to be the number of particular grades obtained in the final test by students in both groups. The data was used 
as a basis for obtaining further statistics. It was also assumed that a student's activity in the class is a measure of knowledge acquisition.

b) Being active during the classes, that is the assessment of changes in attitudes and behaviour of individuals when performing tasks. Here, the observation of students' behaviour by the class instructor and the graphically represented data obtained from the EEG tests in the experimental group were used as indicators. Using the QEEG to track the brain waves of the particular frequencies makes it possible to observe the activity of the particular brain regions when one is learning. This can be directly equated with cognitive activity occurring during classes. In EEG it is possible to analyse changes in the potential generated by brain cells, i.e. the brain's spontaneous activity occurring in response to external complex stimuli coming from the simulation programme. The results of the experiments were thoroughly analysed by an EEG technician. It was found out that under the influence of visual and auditory stimuli in the form of animations, narratives, and solving the tasks included in the simulation programme, the brain changes temporary frequency of selected waves. This results in an observable change in the kind of brain activity from relaxation (dormant state) to the state of full concentration and alertness. The paper does not aim to link EEG parameters with different teaching methods but it offers a reliable method for examining the dependent variable in the experimental group.

The division of students into the control and experimental group differed as far as the initial level of students' knowledge and their average marks of analyzed subjects were concerned. Due to the fact that marks from particular subjects could have been subjective, I created the test concerning the basics of computer science and electrotechnology in order to check their knowledge.(Tab.1) The analysis of the results - made in a correct manner showed the actual level of students' knowledge. Groups with a lower average marks were assigned to the experimental groups and students with higher average marks to the control group. Due to the fact that the average marks did not significantly differ from each other, it was possible to state that students represented a similar state of knowledge. The group members were selected in the way as stated, since the level of the input knowledge was clearly determined and, in my opinion, it was not a factor which could affect the final assessment of results obtained in both groups. Besides, selecting the group members of slightly lower input level was motivated by the desire to compensate for the differences among students and assist those whose academic performance may be weaker.There exists a large correlation between the content of teaching subjects and the ability to share it. It is essential to teach students the methods of instruction and the manner to share the content, which requires not only 
theoretical knowledge, but also practical knowledge in taking actions, developing skills in choosing the work methods, communication with students, and skills in establishing the cooperation. In order to evaluate whether the effect of teaching in the control group and in the experimental group was comparable or differed in the two groups, I conducted the final test. Poland has a grading scale: 5-highest, 4, 3, 2-lowest. The results obtained gave me the possibility to compare the marks in two groups. I used the method of the statistical analysis using a non-parametric test for independence chi-square distribution, for the purpose of a closer analysis of the data and the indications whether the didactic aids used in the experimental group had an essential influence on the level of students' knowledge. The analysis of the collected data consists in an attempt to verify the hypothesis that two qualitative features in the population are independent. Due to this method one can make sure, whether data contracted in the many-divided board delivers a sufficient proof for the relation between the two variables. The analysis of the results confirmed the hypothesis of the research and induced me to formulate the present conclusions.

The second method - at the same time, the studies were performed on selected students in experimental groups with medical equipment for analyzing brain waves in EEG (electroencephalography), too. The presence of an EEG rhythm indicates activity of individual neural cells at a certain location and corresponds to electrical pulses forming rhythmic patterns of brain waves. For each band of waves generated by the brain, a specific type of neurotransmitters is produced, which affect the functioning of the organism. The measurements of currents generated by neurons in the idle state show that the patterns recorded in the stage of the experiment for different individuals are different. This is due to the fact that various people have different abilities, disorders, or preferences. It has to be noted that the present work is to be treated as a pilot study which has to be followed by a more comprehensive research. Still, the results obtained appear to be significant and interesting, particularly to pedagogues. Pedagogy, as a science focused on the human being, often draws on the findings of medicine and psychology. New interdisciplinary labels, such as neuropedagogy or neurodidactics have attracted interest of pedagogues (Żylińska, 2013). The objective that neurodidactics seeks to meet is to design a new brain-friendly method of teaching and learning. Thus, from the viewpoint of the teacher's work, neurodidactics seems to be a very attractive and promising notion.

The presence of an EEG rhythm indicates activity of neural cells at a certain location and corresponds to electrical pulses forming rhythmic patterns of brain waves. For each band of waves generated by the brain, a specific type of neurotransmitters is produced, which affect the functioning of the organism. The best known neurotransmitters include adrenaline, noradrenaline, dopamine, serotonin and endorphins. All the brain wave components are generated all the time but some of them can be fostered at will and by systematic training. By increasing the share of the desired wave bands, we automatically increase the 
production of the neurotransmitters and affect the functioning of our organism, boosting the activity of the brain regions which are the most important for learning. Electromagnetic signals were recorded from electrodes located at various places of the scalp and body such that they show the highest degree of activity: analyzing colours, motion, shape, depth, visual associations, assessment and making decisions, auditory perception, speech comprehension, object recognition, object categorization, understanding symbols, abstract notions and geometrical relations, meaning of words, identifying situations, working memory, volition, temporal relations, control over a sequence of events, planning, responses to external stimuli and simulations in the model of the world. The participants, who volunteered to take part in the experiment, were selected in a random way. It has to be noted that the tests are non-invasive and do not have any negative influence on health. They were carried out in two stages at the Biofeedback Experimental Lab at the Jan Długosz University in Częstochowa. The stage consisted in analyzing the brains' operation in the same individuals during activities performed while working with a multimedia computer programme. The programme exploits effects of simulating the operation of digital systems.

\section{Results of Research}

Table 2. Population of students

\begin{tabular}{|l|l|l|}
\hline Group & Population & \% \\
\hline control & 73 & 61,8 \\
\hline experimental & 45 & 38,2 \\
\hline sum & 118 & 100 \\
\hline
\end{tabular}

Table 3. Test $\chi^{2}$

\begin{tabular}{|l|l|l|}
\hline test value $\chi^{2}$ & degrees of freedom & The level of significance \\
\hline 61,2 & $\mathrm{df}=2$ & $\mathrm{p}<0,001$ \\
\hline
\end{tabular}

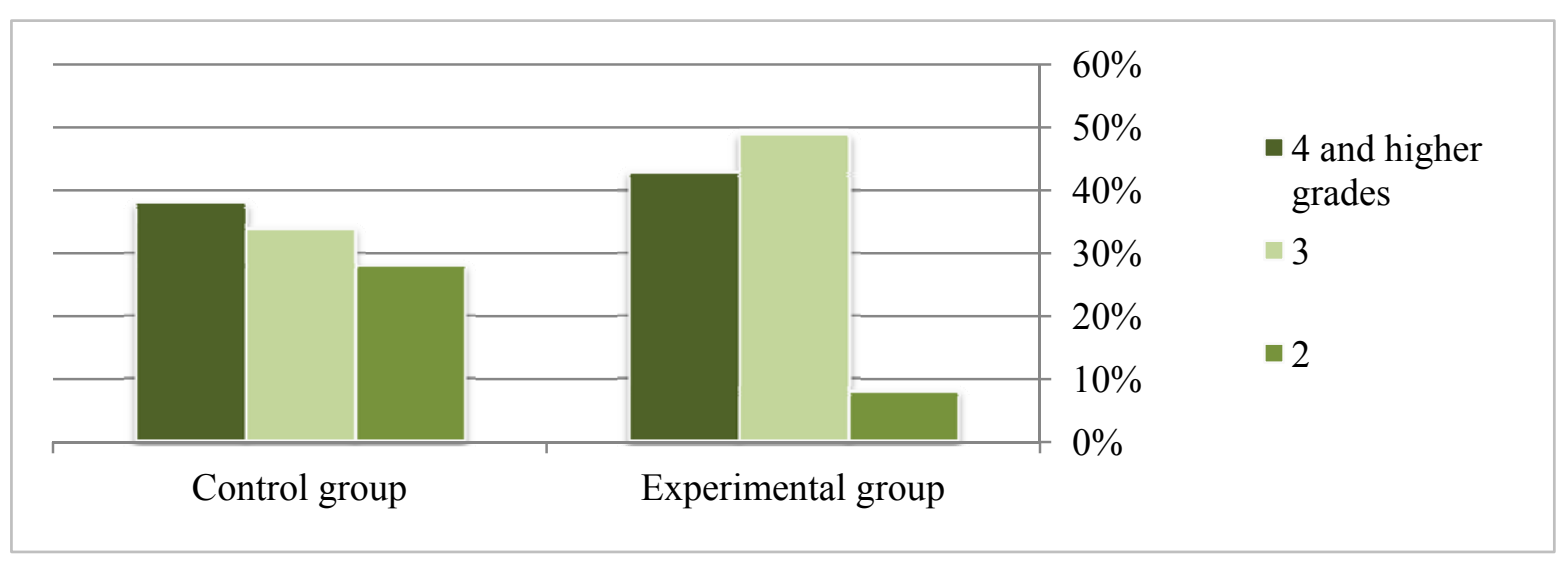

Figure 3. Scheme two-dimensional: ESTIMATION - GROUPS 
Since the calculated $\chi^{2}=61,2$ is greater than the critical $\chi^{2}=5,991$ it can be concluded that the variables are tied. We therefore reject the null hypothesis that the features examined are independent and we assume the alternative hypothesis that there is a significant relationship between the features.

The following recorded wave bands were analyzed:

- THETA It is referred to as a gate to learning and memory, as it accompanies creative processes and learning. It reduces stress, enhances intuition and other super-sensory kinds of perception and skills. It represents subjective emotional states of intuition, creativity, fantasizing, imagery. The excess of THETA waves lowers concentration, causes difficulties in focusing on the learning process and deteriorates cognitive performance. Theta waves of the frequency $4-8 \mathrm{~Hz}$ are of crucial importance in memorising. These waves are related to the activity of the limbic system responsible for experiencing emotions. Strong emotions, especially positive ones facilitate memorising but the optimal condition of the mind is achieved with gamma waves being dominant.

- $\quad$ BETA1 It is closely linked to inspiration and energy, accompanying activity, logical and analytical thinking, intellectual involvement and verbal communication. Beta waves of higher frequencies indicate aggression or anxiety. It represents subjective emotional states of alertness and concentration. Tasks are completed fast and with ease. Neurons travel at a very high speed. One can fulfill ambitious aims and reach for the top. New ideas emerge instantly.

- GAMMA represents subjective emotional states of thinking, integrative thinking and associative processes. Activities and behaviour: processing information of high degree of difficulty, combining various modalities and associations. Gamma waves are believed to represent the most efficient mental effort and creative work.

The studies were carried out during the student's work with the simulation program.

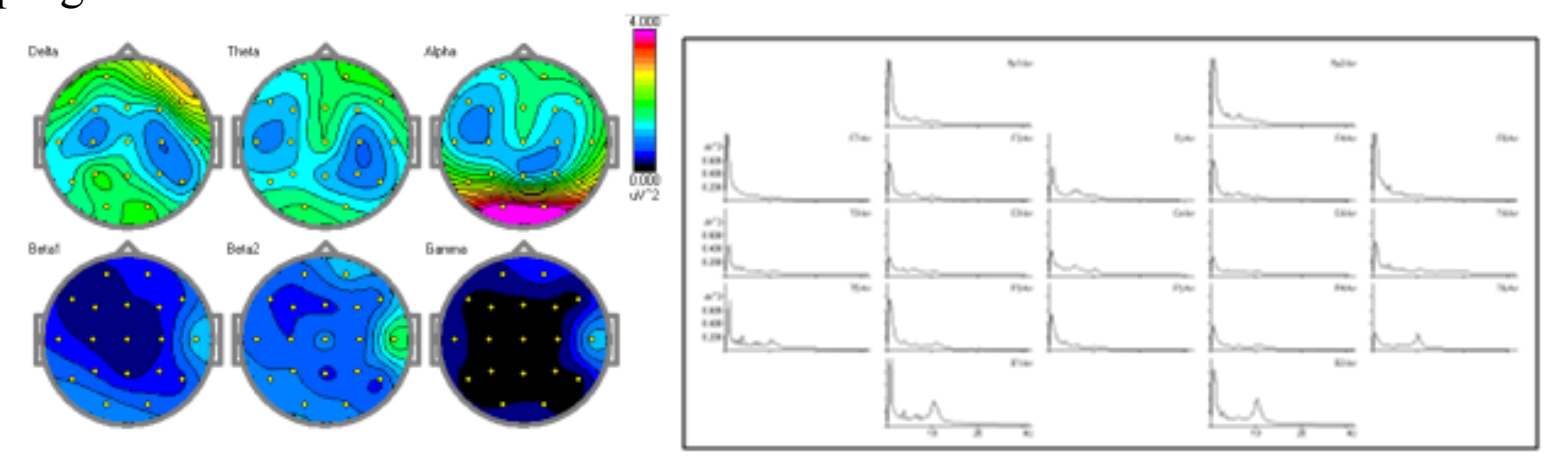

Figure 4. The example: student's map of power of an EEG spectrum expressed in $\mu \mathrm{V}$ for various frequencies (wave type-activity state) and power spectrum graphs. 


\section{Conclusions}

- Modern didactic aids helps develop students' abilities by boosting the following: learning, thinking, searching abilities, ability to act, communication skills and co-operation.

- A number of conducted researches has proved that the use of new didactic measures undoubtedly has a positive impact on the didactic process. Of course, it is difficult to mention only the positive values of the given didactic aid, because there are some of the measures which have a negative influence, although they should support this process. It is necessary to carefully evaluate their usefulness, because often the novelty of a given aid does not guarantee its usefulness. The introduction of didactic aids during classes should be based on special evaluation by the person who conducts classes. In many cases, the introduction of new aids, will not only make the didactic process less attractive, but also will not arise the interest of students.

- The presence of an EEG rhythm indicates that the brain is engaged in some activity, in which millions of neurons can be participating in a synchronized mode. The amplitude of the currents generated by neurons for the various frequencies measured at various electrode locations increases as a result of activating the brain lobes, which, as far as is known, are responsible for specific human behavioural patterns and actions.

- Using the EEG-based method makes it possible to assess an individual's input conditions, related to his/her aptitude for certain cognitive tasks and possibly related to previously acquired skills.

- It can be observed that the brain is active all the time, regardless whether it is in idle state or engaged in intense work. Because of that, all stimuli reaching the brain affect its operation, also by interfering with it. Taking the effectiveness of learning into account, this means that the exterior conditions accompanying learning should be appropriate and free from signals which can potentially distract the mind from working on a task.

- The effectiveness of learning depends not only on the time but also on the depth of information processing. That means that the quality of learning materials and the student's involvement in the process of learning are conducive to educational success. The simulation programme is rich in didactic properties and stimulates practically all the brain areas, which was observed in the majority of subjects.

- During the experiments, some differences in brain activation were also observed among the individuals, and the brain activity was not always fully predictable. It has to be therefore concluded that simulation programmes can be received differently by different people.

- Using the experimental factor, i.e., the simulation programme significantly boosted the activity of the particular brain regions, which was testified by 
the recorded waveforms showing characteristic excitation of the brain during the learning process.

\section{References}

Barski, T. (1998). Technologia ksztatcenia nauczycieli techniki. Uniwersytet Opolski: Śląskie Przedsiębiorstwo „OPCJA-IPO” Publisher.

Carr, N. (2012). The Shallows: What the Internet Is Doing to Our Brains.W.W. Norton

Freedman, T. (2011). The educational technology site. Downloaded from http://www.ictineducation.org

Gerhard, P. (2011). Insight observatory for new technologies and education. Downloaded from http://www.xplora.org

Janiczek, R., Ptak, P. (2007). Przetworniki indukcyjnościowe w pomiarach grubości warstw wierzchnich. Przeglad Elektrotechniczny, NR 1/2007, 86-90. ISSN 0033-2097

Majewska, M. (2014). Elektroencefalografia (EEG) to badanie rozpoznajace choroby mózgu. Na czym polega EEG? Downloaded from http://www.poradnikzdrowie.pl

Morbitzer, J., In: Prensky, M. (2009). Cyfrowi tubylcy i imigranci. Downloaded from http: //www. edunews.pl

Prauzner, T. (2010). Applications of multimedia devices as teaching aids. In: Szczygieł R. (Eds.) Annales UMCS Informatica. (pp. 167-175). Lublin: Maria Curie-Skłodowska University Publisher.

Prauzner, T., Ptak, P. (2014). Analiza parametrów pracy wybranych czujników pola magnetycznego. Przeglad Elektrotechniczny, R. 90 NR 12/2014, 273-276. ISSN 00332097

Prensky, M. (2011). Mark Prensky, Practical, Visionary. Downloaded from http://www.marcprensky.com

Ptak, P., Borowik, L. (2012). Dobór częstotliwości i rodzaju sygnału czujnika indukcyjnego na potrzeby pomiaru grubości wielowarstwowych powłok ochronnych. Przeglad Elektrotechniczny, NR 12b/2012, 245-247. ISSN 0033-2097

Ptak, P., Prauzner, T. (2013). Badanie czujników detekcji zagrożeń w systemach alarmowych. Przeglad Elektrotechniczny, NR 10/2013, 274-276. ISSN 0033-2097

Żylińska, M. (2013). Neurodydaktyka. Nauczanie i uczenie się przyjazne mózgowi. Toruń: Wydawnictwo Naukowe UMK 